\title{
Liquid Steel Treatment in the Ladle with Non-oxidizing Synthetic Slag*
}

\author{
By Kazuo OKOHIRA, ,* Nobuo SATO, ${ }^{* *}$ and Hisashi MORI***
}

\section{Synopsis}

Synthetic slags with low $\mathrm{FeO}$ content were produced by way of trial with a view to purifying liquid steel by preventing its reoxidation by the slag in the ladle. Using the 1-ton E.F., low-carbon aluminium-killed steel was tested on a semi-industrial scale.

The effects of slags and lining materials by types were investigated, and the following results were obtained:

(1) If the $\mathrm{FeO}$ content in slag in the ladle is decreased to less than $2 \%$, liquid steel is purified and the total oxygen decreases to below $40 \mathrm{ppm}$. Large inclusions $(\geqq 100 \mu)$ are eliminated.

(2) Loss of sol. Al in liquid steel is caused not only by slag but also by lining material. In the case of treatment with synthetic slag, relative contribution of lining material to the loss of sol. Al is greater than in the case of treatment with normal slag. However, this contribution can be suppressed by the use of a lining material with high $\mathrm{Al}_{2} \mathrm{O}_{3}$ content.

(3) The velocity of sol. Al loss is controlled by the diffusion of oxygen in the slag.

\section{Introduction}

It is known that when liquid steel in the ladle is stirred by blowing argon gas therein from the bottom of the ladle or by any other methods, floatation and separation of suspending inclusions are promoted, thereby to purify the liquid steel and to decrease the total oxygen content ${ }^{1)}$ therein. However, in the case of low-carbon aluminium-killed steel for which the slag flowing out of the LD-converter into the ladle has a very high oxidizing potential, the total oxygen in the liquid steel is hardly decreased, because of the oxidation of liquid steel by slag, even if argon bubbling is performed. ${ }^{2)}$ With a view to reducing oxidation of liquid steel, therefore, the purifying effect to be obtained by replacing this slag with a non-oxidizing synthetic slag with low FeO content and the effect of ladle lining material on low-carbon aluminium-killed steel were investigated by conducting semi-industrial tests on 1-ton scale using the synthetic slags produced by way of trial.

\section{Test Methods}

The steel selected for testing is low-carbon aluminium-killed steel, having the desired composition as shown in Table 1, which is most likely to be reoxidized by slag on account of the properties of slag and the composition of liquid steel.

Table 1. Aim compositions of test heat

\begin{tabular}{c|cccccc}
$\begin{array}{c}\text { Compositions } \\
(\%)\end{array}$ & C & Si & Mn & P & S & sol. Al \\
\hline $\begin{array}{c}\text { Low C-Al- } \\
\text { killed steel }\end{array}$ & $\begin{array}{c}0.03 \\
\text { ? } \\
0.05\end{array}$ & $<0.02$ & $\begin{array}{c}0.30 \\
\text { ? } \\
0.40\end{array}$ & $<0.02$ & $<0.02$ & $\begin{array}{c}0.030 \\
? \\
0\end{array}$ \\
\hline
\end{tabular}

\section{Selection of Composition of Synthetic Slag}

The slag which is most suitable for the abovementioned objective must have the following characteristics:

(i) Low oxygen potential

(ii) Ease of absorption of inclusion $\left(\mathrm{Al}_{2} \mathrm{O}_{3}\right)$

(iii) Low melting point and high fluidity.

The slag having these characteristics is of the $\mathrm{CaO}-\mathrm{Al}_{2} \mathrm{O}_{3}-\mathrm{SiO}_{2}$ system. The physical properties of this slag were controlled by adding $\mathrm{AlF}_{3}, \mathrm{NaAlF}_{4}$, $\mathrm{Na}_{2} \mathrm{CO}_{3}$, and others thereto in small quantities. To suppress its oxygen potential, it is desirable to reduce the amount of $\mathrm{FeO}$ and $\mathrm{MnO}$ contents of it as much as material blending can permit. In Fig. 1, the synthetic slags mentioned in the references, ${ }^{3-8)}$ LD-converter slag and blast furnace slag having the typical compositions and refractories for ladle and powder for continuous casting are plotted on the phase diagram of the $\mathrm{CaO}-\mathrm{Al}_{2} \mathrm{O}_{3}-\mathrm{SiO}_{2}$ system. When assumed that the melting point of slag is preferably lower than $1300^{\circ} \mathrm{C}$, the composition of the slag will be limited to three ranges with the following three points.

$\begin{aligned} \text { I: } & \mathrm{CaO}-\mathrm{SiO}_{2}-\mathrm{Al}_{2} \mathrm{O}_{3}=38: 42: 20 \\ \text { II } & \mathrm{CaO}-\mathrm{SiO}_{2}-\mathrm{Al}_{2} \mathrm{O}_{3}=50: 7: 43 \\ \text { III } & \mathrm{CaO}-\mathrm{SiO}_{2}-\mathrm{Al}_{2} \mathrm{O}_{3}=22: 63: 15\end{aligned}$

According to the iso-activity lines of $\mathrm{Al}_{2} \mathrm{O}_{3}$ and $\mathrm{SiO}_{2}$, which are shown in Fig. 2, the slag compositions I and II, excluding III, are suitable for suppressing the activity of $\mathrm{SiO}_{2}$ as much as possible in the range where the activity of $\mathrm{Al}_{2} \mathrm{O}_{3}$, the main constituent of

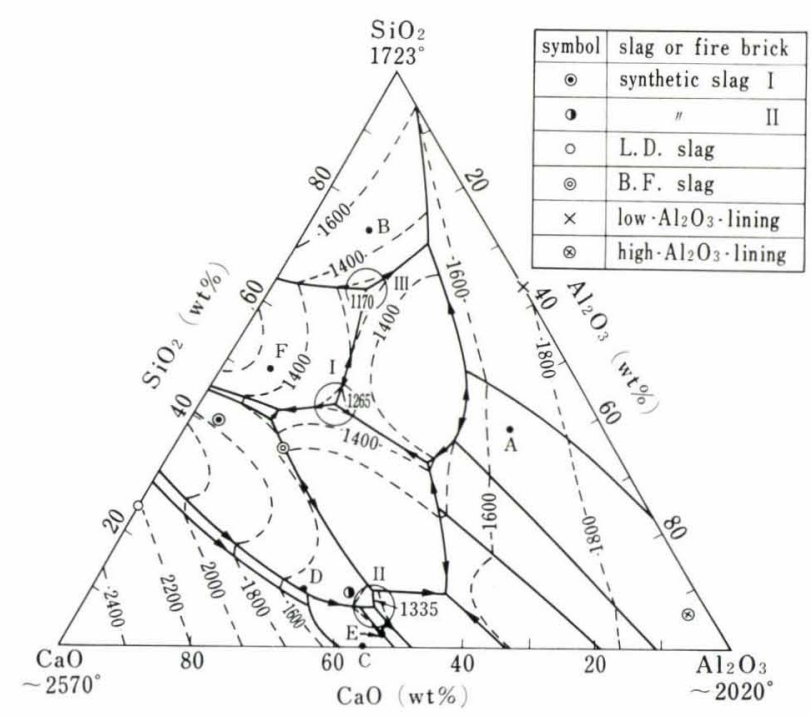

Fig. 1. Phase equilibrium diagram of $\mathrm{CaO}-\mathrm{Al}_{2} \mathrm{O}_{3}-\mathrm{SiO}_{2}$ system $^{9)}$

* Originally published in Tetsu-to-Hagané, 60 (1974), 192, in Japanese. English version received December $27,1973$.

k* Technical Research Institute, Yawata Works, Nippon Steel Corporation, Edamitsu-cho, Yawata-higashi-ku, Kitakyushu 805. 
inclusions in aluminium killed steel, is low. As plotted in Fig. 1, any equivalent of composition I approximates that of powder $(F)$ used for continuous casting and of blast furnace slag (@)).

The composition of slags such as $C,{ }^{6)}, D,{ }^{7)}$ and $E^{8)}$ mentioned in the references resembles composition II.

With a view to lowering the melting point even if the composition is changed due to enrichment of $\mathrm{Al}_{2} \mathrm{O}_{3}, \mathrm{SiO}_{2}$, and others, the synthetic slag I (S-slag I) containing $\mathrm{CaO} / \mathrm{SiO}_{2} \sim 1$ and basic synthetic slag II ( $S$ slag II) containing $\mathrm{CaO} / \mathrm{SiO}_{2} \sim 4$, both having the desired composition as shown in Table 2, were produced by way of trial. Experiments were conducted mainly using $S$-slag I having a wide range of low melting points.

\section{Test Procedure}

After the steel to be tested was melted down in the 1-ton E.F., oxygen was blown into it so that its carbon content became 0.03 to $0.04 \%$ and its total oxygen content became 600 to $700 \mathrm{ppm}$ before tapping. At the time of tapping, $\mathrm{Fe}-\mathrm{Mn}$ and $\mathrm{Al}$ were charged so that the steel attained the desired composition after slag off. Synthetic slag was added at the end of tapping and argon gas blown in from the early stage of tapping, while the hourly changes in composition of slag and liquid steel as well as the amount of inclusions were examined.

Slag samples were taken by a steel spoon at intervals of 3 to $5 \mathrm{~min}$. Liquid steel samples were taken

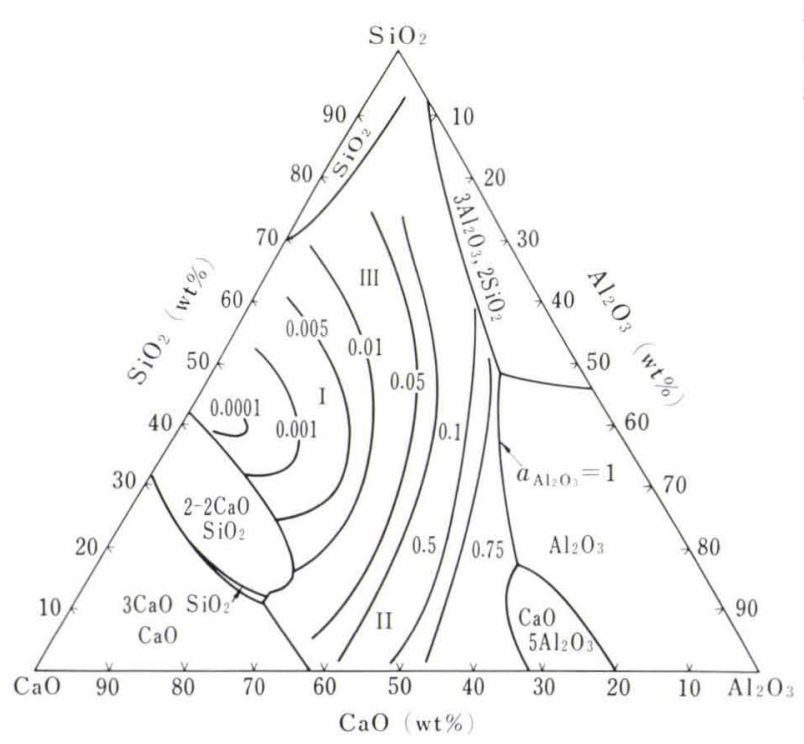

Fig. 2. Isoactivity lines of $\mathrm{Al}_{2} \mathrm{O}_{3}$ and $\mathrm{SiO}_{2}$ on the system $\mathrm{CaO}-\mathrm{SiO}_{2}-\mathrm{Al}_{2} \mathrm{O}_{3}$ at $1630^{\circ} \mathrm{C}^{10,11)}$

Table 2. Properties of slags

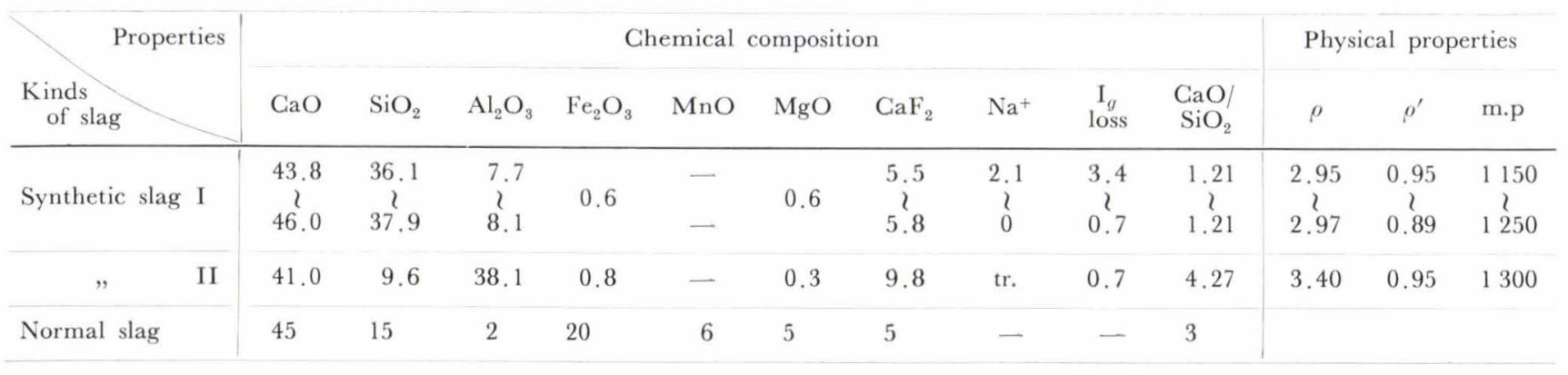

at intervals of 0.5 to $2 \mathrm{~min}$ by means of a steel bomb of $40 \phi \times 70 \mathrm{~mm}$ in inner size and $10 \mathrm{~mm}$ in thickness. The analysis and observation of inclusions by microscope was conducted at the cross section at a height of $20 \mathrm{~mm}$ above the bottom of the bomb.

The main dimension of the ladle used for test are shown in Fig. 3. The liquid steel-slag interface is $600 \mathrm{~mm}$ in diameter and the liquid steel head is $500 \mathrm{~mm}$. Synthetic slag is required an amount of 6 to $15 \mathrm{~kg}$ to suppress the rising of melting point occurring in accordance with changes in slag composition caused by $\mathrm{Al}_{2} \mathrm{O}_{3}$ (about $1.5 \mathrm{~kg}$ ) to be formed on the assumption that the whole amount of oxygen content of liquid steel at the tapping, is converted into $\mathrm{Al}_{2} \mathrm{O}_{3}$. In testing, therefore, the slag was used in a quantity of 10 to $20 \mathrm{~kg}$ per heat. If the liquid steel is stirred at a high flow rate of argon gas, the surface of liquid steel is exposed. The test, therefore, was conducted with the argon flow controlled at 3 to $10 \mathrm{~N} / / \mathrm{min}$ so as to avoid exposure of the liquid steel. To protect the surface of molten steel in case when the flow rate of argon gas is high, carbonized chaff was added in an amount of 2.5 to $5 \mathrm{~kg}$ to prevent air oxidation of liquid steel which, however, could not be sufficiently prevented. A considerably large amount of carbon pickup on the other hand was observed, and so addition of carbonized chaff was limited to a small number of heats. To further decrease the amount of $\mathrm{FeO}$ in the synthetic slag, deoxidizers such as $\mathrm{Al}, \mathrm{Si}$, or $\mathrm{Ca}-$ Si may be added to the synthetic slag. Because, however, of the limitation imposed on the steel that Si content should be low, powdered aluminium was added and its effect was investigated.

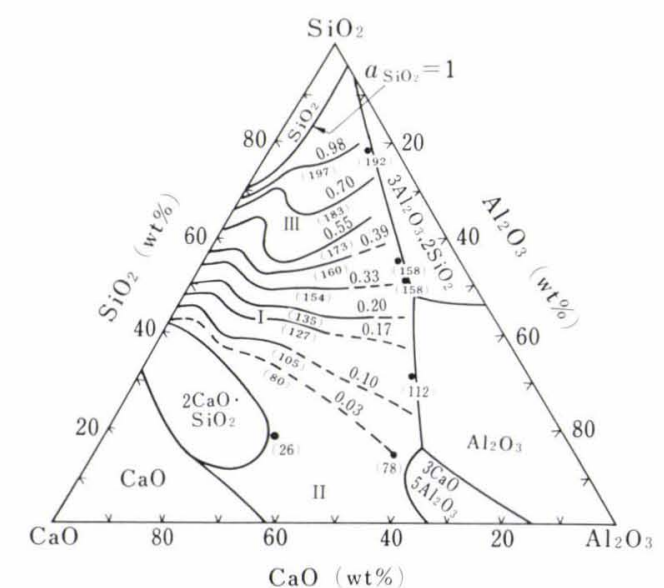


The chamotte refractory (low $\mathrm{Al}_{2} \mathrm{O}_{3}$ ) having the composition as shown in Table 3 was used as a ladle lining material. Further, a coating material with high $\mathrm{Al}_{2} \mathrm{O}_{3}$ content was used to prevent silicon pickup during treatment, and the results were compared.

\section{Test Results}

Table 4 shows the analytical values of metal and slag in test heats as classified according to the test conditions. The heat asterisked in the "Note" colum indicates that in which the liquid steel was exposed by about $10 \%$ of the area of liquid steel-slag interface, and that in which the liquid steel was presumably in direct contact with the carbonized chaff judging from the large quantity of carbon pick up formed at the time of its addition. These heats are the ones in which the N-pick up $(\Delta N)$ is large and the degree of air oxidation of liquid steel presumably is considerably high. In the heat in which powdered aluminium was added to the synthetic slag, the amount of $\mathrm{FeO}$ contained therein was the lowest.

\section{Contribution of Various Reactions to Oxidation of Alu- minium in Liquid Steel}

The causes of the decrease in the amount of sol. Al due to the reoxidation of liquid steel in the ladle to be caused at the time of argon bubbling are presumably the following:

(i) Air oxidation of sol. Al

(ii) Oxidation by $\mathrm{FeO}, \mathrm{MnO}$ and the like contained in the slag

(iii) Oxidation of sol. Al by $\mathrm{SiO}_{2}$.

Based on the amount of pickups of $\underline{\mathrm{Si}}$ and $\underline{\mathrm{N}}$ and the decrease in sol. Al, which are shown in Table 4, loss of sol. Al was estimated by causes on the following assumptions:

(1) By the reduction of $\mathrm{SiO}_{2}, \underline{\mathrm{Al}}$ is lost in an amount which is stoichiometrically equivalent to the amount of Si-pick up ( $\triangle \mathrm{Si})$.

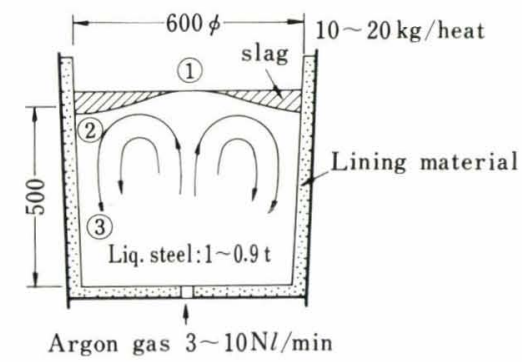

$\begin{array}{ll}\text { (1) Al-loss caused by } \mathrm{SiO}_{2} \text {-reduction } & 0.012(\%) \mathrm{Al} \\ \text { (2) Al-loss caused by slag } & 0.008(\%) \mathrm{Al} \\ \text { (3) Al-loss caused by air-oxidation } & 0.034(\%) \mathrm{Al}\end{array}$

Fig. 3. Ladle dimension
(2) The amount of sol. Al oxidized by air is proportional to the amount of $J \mathrm{~N}$. (Fig. 4.)

(3) The loss due to reaction with slag is obtained by substracting the sum of the losses mentioned in the assumptions 1 and 2 above from the total loss of sol. Al.

The heats were divided into two groups, i.e., the group in which the amount of $\Delta \mathrm{N}$ was small and consequently the loss of sol. Al by air was small, and the group in which the loss of sol. Al was great, and the average value of contribution of each reaction is given in Table 5 . When treating with normal slag $(\mathcal{N}$-slag $)$, the loss of sol. Al thereby is decidedly great, i.e., several times as great as the loss due to reaction with $\mathrm{SiO}_{2}$. When treating with $S$-slag, however, the contribution of reaction with $\mathrm{SiO}_{2}$ is greater than the loss of sol. Al by the slag. In the case of $S$-slag treated heat for which a ladle lined with high $\mathrm{Al}_{2} \mathrm{O}_{3}$ material for suppressing its reaction both with $\mathrm{SiO}_{2}$ and with air is used, loss of sol. Al by slag occupies the most part of the loss. In case air oxidation is so great that the amount of $\Delta \mathrm{N}$ reaches $7 \mathrm{ppm}$ during the treatment of about $15 \mathrm{~min}$, it is considered that the contribution of air, $\mathrm{SiO}_{2}$, and slag becomes smaller in the order mentioned.

As an example, Fig. 5 (see p. 342) shows the hourly changes in sol. Al and total oxygen at the time of argon bubbling, respectively in the heat (No. 9) in which there was no exposure of molten iron surface when treated with $S$-slag I using a ladle lined with low $\mathrm{Al}_{2} \mathrm{O}_{3}$ material, in the heat (No. 7) in which the surface of molten iron was exposed by about $10 \%$ of the total area, and in the heat (No. 3) in which there was no exposure of molten iron surface when treated with the $\mathcal{N}$-slag. In the $\mathcal{N}$-slag treating heat, the decrease in sol. Al is quick and the total oxygen becomes the lowest when the amount of sol. Al has decreased to below $0.020 \%$. In the $S$-slag treating heats, there is no example where the amount of sol. Al becomes extremely low during treatment. Accordingly, the point at which the total oxygen became nearly constant as shown in Fig. 5 was taken as the minimum value of total oxygen and was used for subsequent analysis. In the heat (No. 7) in which the exposure of molten iron surface is large, the decrease in sol. Al is great and the value of total oxygen is high. The behaviour of total oxygen is not satisfying the logarithmic law. ${ }^{12}$ ) The reason may be that the physical properties of liquid steel are changed with the rapid temperature drop during treatment. Another reason may presumably be that new inclusions are formed by the reoxidation of liquid steel, while the inclusions are floating up and being eliminated, and part of them are trapped in the liquid steel.

Table 3. Chemical compositions of lining materials of ladle

\begin{tabular}{ccccccccccc}
\hline $\begin{array}{l}\text { Kinds of } \\
\text { lining materials }\end{array}$ & $\mathrm{Al}_{2} \mathrm{O}_{3}$ & $\mathrm{SiO}_{2}$ & $\mathrm{Fe}_{2} \mathrm{O}_{3}$ & $\mathrm{CaO}$ & $\mathrm{MgO}$ & $\mathrm{TiO}_{2}$ & $\mathrm{Na}_{2} \mathrm{O}$ & $\mathrm{K}_{2} \mathrm{O}$ & $\mathrm{I}_{g}$ loss \\
\hline Low- $\mathrm{Al}_{2} \mathrm{O}_{3}$ & $\mathbf{3 4 . 7}$ & $\mathbf{5 9 . 9}$ & 2.56 & 0.3 & 0.4 & 1.07 & 0.47 & 0.02 & 0.72 \\
\hline High- $-\mathrm{Al}_{2} \mathrm{O}_{3}$ & $\mathbf{8 9 . 8}$ & $\mathbf{1 . 4 5}$ & 1.75 & 5.0 & 0.2 & 0.44 & 0.47 & 0.02 & 0.72 \\
\hline
\end{tabular}


Table 4. Results

\begin{tabular}{|c|c|c|c|c|c|c|c|c|c|}
\hline \multirow{3}{*}{ Kinds of slag } & \multirow{3}{*}{ Ladle lining } & \multirow{3}{*}{$\begin{array}{l}\text { Heat } \\
\text { No. }\end{array}$} & \multicolumn{7}{|c|}{ Metal } \\
\hline & & & \multicolumn{2}{|c|}{ Total O (ppm) } & \multicolumn{4}{|c|}{ sol. $\mathrm{Al}(\%)+10^{3}$} & \multirow{2}{*}{$\begin{array}{c}\Delta \mathrm{Si} \\
\text { Si initial } \\
(\%) \times 10^{3}\end{array}$} \\
\hline & & & initial & at $\min *$ & initial & $\begin{array}{c}\text { at }(\mathrm{T} . \mathrm{O}) \\
\text { min** }\end{array}$ & $\Delta$ sol. $\mathrm{Al}$ & $\frac{d \text { sol. } \mathrm{Al}}{d t}$ & \\
\hline \multirow{6}{*}{ Normal slag } & \multirow{4}{*}{ Low- $\mathrm{Al}_{2} \mathrm{O}_{2}$} & 1 & 264 & 82 & 150 & 80 & 70 & 17 & $20 / 8$ \\
\hline & & 2 & 226 & 125 & 65 & 8 & 60 & 22 & $0 / 20$ \\
\hline & & 3 & 242 & 95 & 157 & 22 & 153 & 25 & $(-18 / 3)$ \\
\hline & & 4 & 155 & 54 & 120 & 64 & 60 & 9 & $7 / 13$ \\
\hline & \multirow{2}{*}{ High- $\mathrm{Al}_{2} \mathrm{O}_{3}$} & 5 & 260 & 192 & 81 & 1 & 80 & 16 & $4 / 6$ \\
\hline & & 6 & 202 & 49 & 189 & 112 & 88 & 11 & $10 / 4$ \\
\hline \multirow{14}{*}{$\begin{array}{l}\text { Synthetic } \\
\text { slag I } \\
(S \text {-slag I) }\end{array}$} & \multirow{9}{*}{ Low- $\mathrm{Al}_{2} \mathrm{O}_{3}$} & 7 & 143 & 77 & 73 & 21 & 54 & 10 & $10 / 18$ \\
\hline & & 8 & 99 & 61 & 132 & 77 & 58 & - & $12 / 15$ \\
\hline & & 9 & 123 & 69 & 75 & 46 & 28 & 4 & $12 / 15$ \\
\hline & & 10 & 102 & 68 & 96 & 73 & 23 & - & $12 / 18$ \\
\hline & & 11 & 155 & 85 & 62 & 32 & 38 & - & $11 / 10$ \\
\hline & & 12 & 133 & 42 & 138 & 85 & 58 & 4 & $24 / 10$ \\
\hline & & 13 & 202 & 73 & 4 & 2 & 3 & - & 0 \\
\hline & & 14 & 142 & 92 & 10 & 1 & 9 & 0 & $7 / 6$ \\
\hline & & 15 & 314 & 65 & 37 & 17 & 24 & 4 & $8 / 8$ \\
\hline & \multirow{5}{*}{ High- $\mathrm{Al}_{2} \mathrm{O}_{3}$} & 16 & 127 & 42 & 81 & 58 & 30 & 4 & $33 / 7$ \\
\hline & & 17 & 135 & 35 & 110 & 76 & 40 & 3 & $2 / 8$ \\
\hline & & 18 & 166 & 46 & 146 & 110 & 36 & 1 & $0 / 13$ \\
\hline & & 19 & 150 & 47 & 151 & 123 & 40 & 3 & $0 / 18$ \\
\hline & & 20 & 195 & 48 & 146 & 101 & 58 & 5 & $0 / 18$ \\
\hline \multirow{2}{*}{$S$-slag II } & \multirow{2}{*}{ Low- $\mathrm{Al}_{2} \mathrm{O}_{3}$} & 21 & 105 & 44 & 62 & 39 & 26 & 3 & $12 / 36$ \\
\hline & & 22 & 107 & 45 & 49 & 26 & 28 & 2 & $9 / 26$ \\
\hline
\end{tabular}

* Minimum total-oxygen value during this refining treatment

** Sol. Al value at the point when Total $\mathrm{O}$ shows minimum value
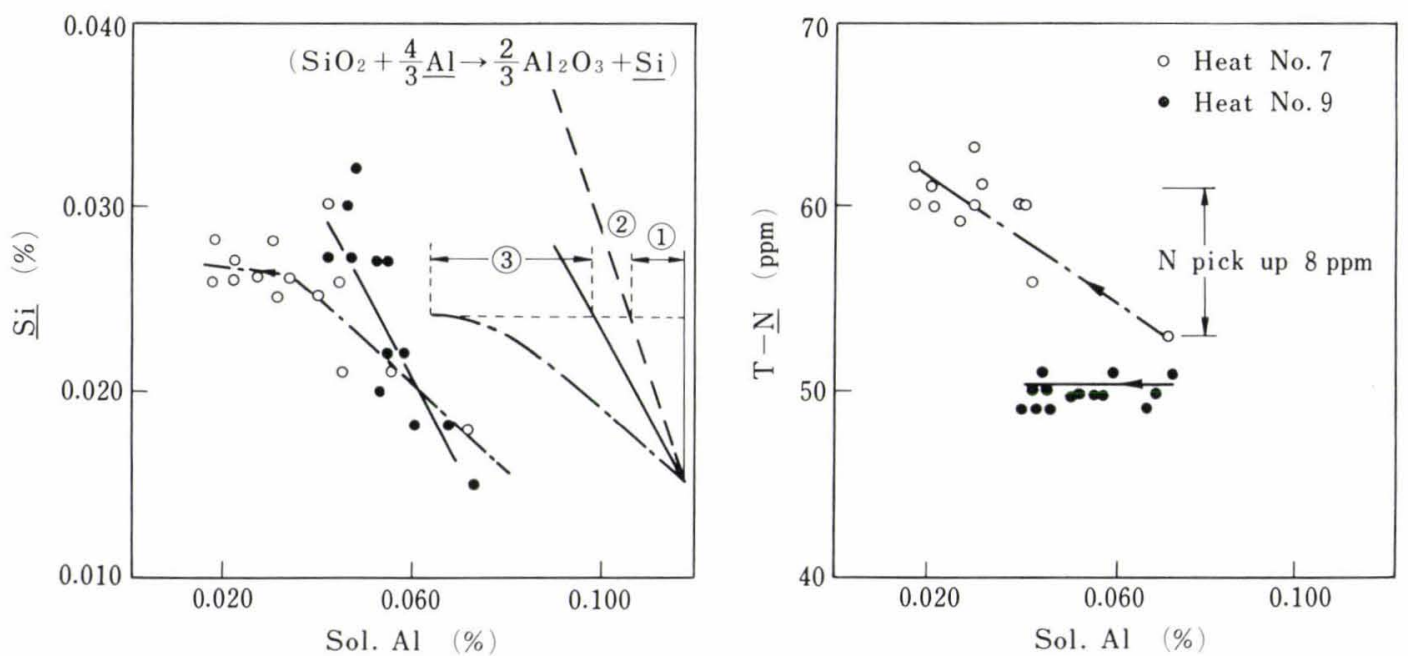

Fig. 4. Presumption of Al-loss caused by air-oxidation

2. Effect of Ladle Lining Material on Reduction of $\mathrm{SiO}_{2}$

Some examples in which $\underline{\mathrm{Si}}$ is increased during treatment are as shown in Fig. 6. In the case of lining material with low $\mathrm{Al}_{2} \mathrm{O}_{3}$ content, $\underline{\mathrm{Si}}$ is increased by more than $0.01 \%$ in about $15 \mathrm{~min}$. Figure 7 shows the amount of $\Delta \mathrm{Si}$ by types of ladle lining materials and slags. It is apparent that the $\Delta \mathrm{Si}$ is decreased greatly by the use of high $\mathrm{Al}_{2} \mathrm{O}_{3}$ lining material.

It is evident from the study of inclusions, described later, that part of $\Delta \mathrm{Si}$ exists in the form of oxides. If it is assumed that the whole amount of $0.01 \% \mathrm{Si}$ exists in the form of $\mathrm{SiO}_{2}$, the amount of oxygen generated thereby may be calculated as follows:

$$
0.01(\%) \times \frac{32(2 \cdot \mathrm{O})}{28(\mathrm{Si})}=0.0114
$$


of experiments

\begin{tabular}{|c|c|c|c|c|c|c|c|c|}
\hline \multirow{3}{*}{$\begin{array}{c}\Delta \mathrm{N} \\
(\mathrm{ppm})\end{array}$} & \multirow{3}{*}{$\underset{(\%) \times 10^{3}}{\mathrm{Mn}}$} & \multicolumn{4}{|c|}{ Slag } & \multirow{3}{*}{$\begin{array}{l}\text { wt of metal } \\
(\mathrm{kg})\end{array}$} & \multirow{3}{*}{$\begin{array}{l}\text { wt of slag } \\
(\mathrm{kg})\end{array}$} & \multirow{3}{*}{ Note } \\
\hline & & \multicolumn{2}{|c|}{$\mathrm{FeO}(\%)$} & \multicolumn{2}{|c|}{$\mathrm{MnO}(\%)$} & & & \\
\hline & & initial & $\begin{array}{c}\text { at }(\mathrm{T} . \mathrm{O}) \\
\min \end{array}$ & initial & $\begin{array}{c}\text { at }(\mathrm{T} . \mathrm{O}) \\
\min \end{array}$ & & & \\
\hline 4 & 33 & 16.2 & 5.8 & 8.5 & 8.7 & 1000 & $>100$ & \\
\hline 0 & 22 & 25.8 & 21.2 & 8.1 & 6.8 & 1000 & 112 & \\
\hline 0 & 20 & 22.8 & 17.3 & 7.4 & 4.7 & 1000 & 125 & \\
\hline (0) & 31 & 10.8 & 7.4 & 9.5 & 10.1 & 1000 & 32 & \\
\hline$(0)$ & 21 & 32.2 & 26.8 & 6.2 & 7.6 & 900 & 106 & \\
\hline$(0)$ & 41 & 15.6 & 6.0 & 11.3 & 12.0 & 1000 & $>100$ & \\
\hline 8 & 32 & 18.2 & 4.4 & 12.5 & 5.8 & 1000 & 20 & $* * *$ \\
\hline 4 & 35 & - & - & - & - & 1000 & 10 & $* * *$ \\
\hline 0 & 33 & 6.4 & 6.0 & 5.5 & 6.9 & 1000 & 20 & \\
\hline 2 & 36 & - & - & - & - & 1000 & 10 & \\
\hline 1 & 35 & - & - & - & - & 1000 & 20 & c.c. 2 \\
\hline 9 & - & 0.7 & 0.7 & 1.8 & 1.8 & 800 & 10 & $\left\{\begin{array}{l}\text { c.c. } 2 * * * * \\
F-\mathrm{Al} 400 * * * *\end{array}\right.$ \\
\hline 5 & - & 2.0 & 1.7 & 3.9 & 3.3 & 900 & 10 & \\
\hline- & 33 & 4.2 & 3.6 & 4.5 & 5.0 & 1000 & 20 & \\
\hline- & 28 & 6.9 & 6.1 & 5.5 & 5.8 & 1000 & 20 & \\
\hline 12 & 41 & 1.1 & 1.2 & 1.4 & 1.4 & 800 & 10 & c.c. $1 * * * *$ \\
\hline 4 & - & 1.9 & 1.3 & 8.9 & 4.7 & 900 & 20 & c.c. $1 * * * * *$ \\
\hline 2 & 43 & 2.5 & 1.8 & 5.4 & 4.9 & 900 & 15 & \\
\hline 0 & 33 & 4.5 & 4.4 & 5.5 & 5.0 & 900 & 15 & \\
\hline 0 & 39 & 3.6 & 1.8 & 3.0 & 3.1 & 900 & 15 & \\
\hline 0 & 42 & 1.0 & 0.8 & 2.4 & 2.5 & 1000 & 20 & \\
\hline 0 & 39 & 1.5 & 1.2 & 3.7 & 3.8 & 1000 & 20 & \\
\hline
\end{tabular}

*** With much $\mathrm{N}$ pickup, that is, strong oxidation by air

**** c.c. : Carbonized chaff, F-Al: Flake-Al

Table 5. Contribution of repective reaction to sol. Al-loss

\begin{tabular}{|c|c|c|c|c|c|c|c|c|c|}
\hline \multirow{2}{*}{$\begin{array}{l}\text { Kinds } \\
\text { of slag }\end{array}$} & \multirow{2}{*}{$\mathrm{K}$ inds of lining } & \multirow{2}{*}{ Selected heats } & \multicolumn{3}{|c|}{$\begin{array}{c}\text { Mean value of variation } \\
\text { of elements }\end{array}$} & \multicolumn{3}{|c|}{$\begin{array}{l}\text { Contribution to } \\
\text { sol. Al-loss }(\%) \times 10^{3}\end{array}$} & \multirow{2}{*}{ Note } \\
\hline & & & $\begin{array}{l}-\Delta \text { sol. Al } \\
(\%) \times 10^{3}\end{array}$ & $\begin{array}{l}\Delta \mathrm{Si} \\
(\%) \times 10^{3}\end{array}$ & $\begin{array}{c}\Delta \mathrm{N} \\
(\mathrm{ppm})\end{array}$ & $\begin{array}{l}\text { by } \\
\Delta \mathrm{Si}\end{array}$ & $\begin{array}{l}\text { by } \\
\text { air }\end{array}$ & $\begin{array}{l}\text { by } \\
\text { slag }\end{array}$ & \\
\hline \multirow{2}{*}{$\begin{array}{l}\text { Normal } \\
\text { slag }\end{array}$} & Low- $\mathrm{Al}_{2} \mathrm{O}_{3}$ & No. $14,19,26$ & 63 & 9 & 1.3 & 12 & 5 & 46 & \multirow{4}{*}{$\begin{array}{l}\text { With less } \\
\text { Al-oxidation } \\
\text { by air }\end{array}$} \\
\hline & High- $\mathrm{Al}_{2} \mathrm{O}_{3}$ & No. 23, 25 & 84 & 7 & 0 & 9 & 0 & 75 & \\
\hline \multirow{2}{*}{$S$-slag I } & Low- $\mathrm{Al}_{2} \mathrm{O}_{3}$ & No. $3,4,6$ & 30 & 12 & 1 & 15 & 4 & 11 & \\
\hline & High- $\mathrm{Al}_{2} \mathrm{O}_{3}$ & No. $17,18,20$ & 45 & 0 & 0.7 & 0 & 3 & 42 & \\
\hline$S$-slag I & Low- $\mathrm{Al}_{2} \mathrm{O}_{3}$ & No. $1,2,13$ & 57 & 5 & 7 & 19 & 28 & 10 & $\begin{array}{l}\text { With much } \\
\text { oxidation by air }\end{array}$ \\
\hline
\end{tabular}

Namely, the amount of oxygen would reach no less than 114 ppm.

In view of the facts that the greater part of inclusions is of $\mathrm{Al}_{2} \mathrm{O}_{3}$ and that the total oxygen is lowered to several tens ppm, it is presumable that most of the analytical values of $\mathrm{Si}$ exist in the form of $\underline{\mathrm{Si}}$. The reason why the $\Delta \mathrm{Si}$ differs considerably as shown in Fig. 7 even if the same low $\mathrm{Al}_{2} \mathrm{O}_{3}$ lining material is used, can be explained by the difference in the composition of the treated liquid steel.

Assuming that the amount of $\triangle \mathrm{Si}$ corresponds to the brick erosion based on the report ${ }^{15)}$ that brick erosion is increased with the increase in the amount of excess $\mathrm{Mn}(\mu: \mu=\mathrm{Mn}-2.15 \mathrm{Si})$ under Fe-O-Mn-Si deoxidation equilibrium, but is decreased if the amount of $\mathrm{Al}$ is high, the relation between $\Delta \mathrm{Si}$ and $\mu$ is shown in Fig. 8. It has been confirmed that the erosion is increased with the increase of $\mu$ even in the range where the content of $\mathrm{Mn}$ is so low as 0.20 to $0.40 \%$. The influence of the level of $\mathrm{Al}$ is shown in Fig. 9, but its effect has not been clarified.

\section{Factors that Control the Total Oxygen in Liquid Steel}

The total oxygen which showed the lowest value during treatment $\left((\text { Total } \mathrm{O})_{\min }\right)$ was taken as a guide to the cleanliness of liquid steel, and the relations between the amount of sol. $\mathrm{Al}$ and the (Total $\mathrm{O})_{\min }$ by types of ladle lining materials and slags have then been 


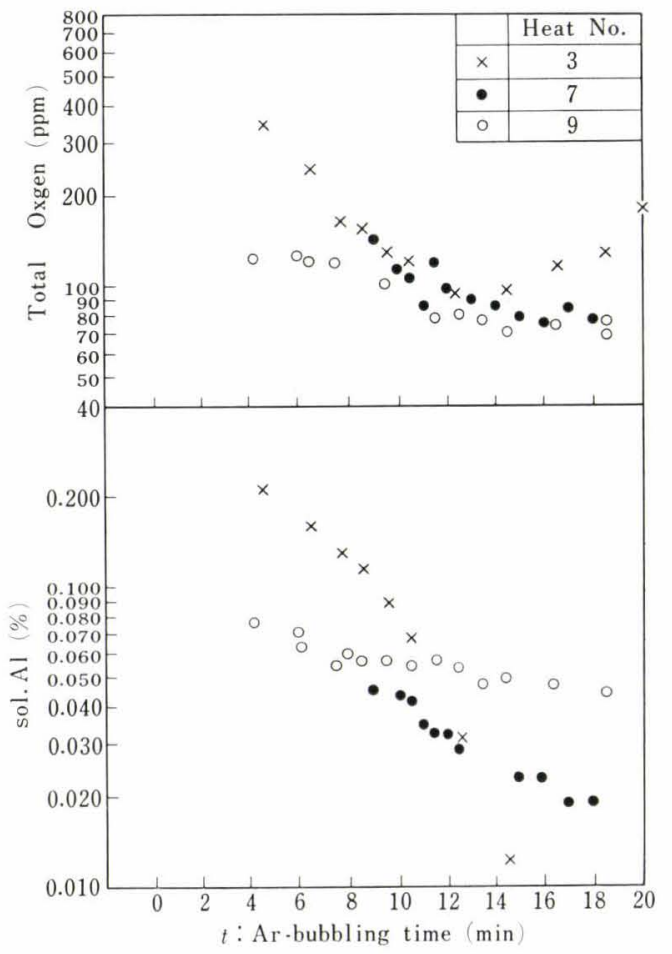

Fig. 5. Change of Total $\mathrm{O}$ and sol. $\mathrm{Al}$ in liq. steel

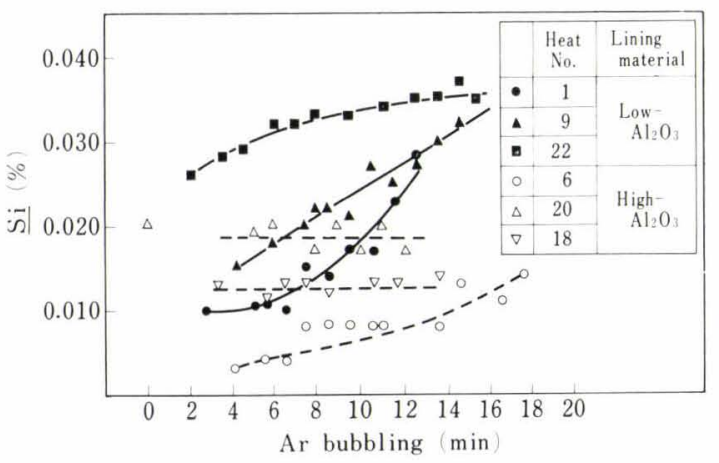

Fig. 6. Change of silicon in liq. steel

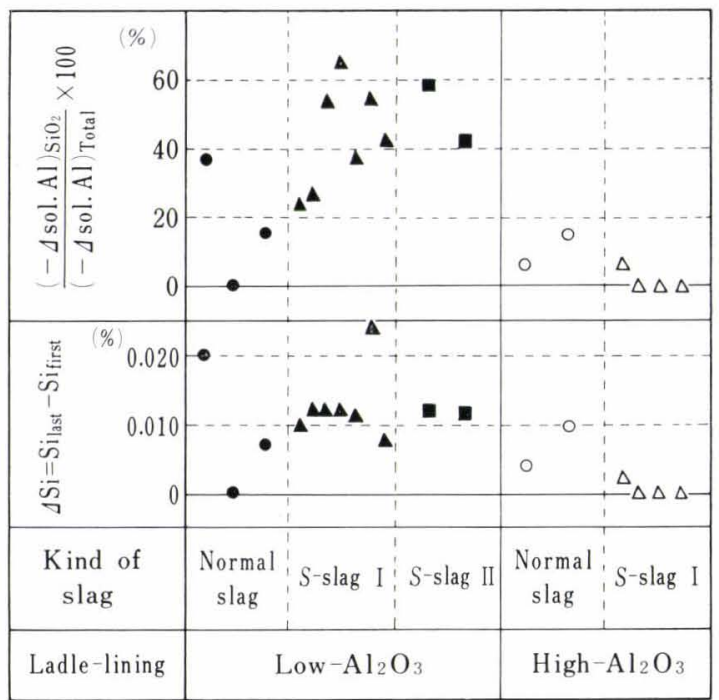

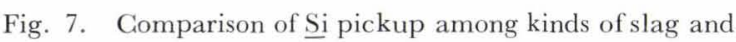
ladle lining

shown in Fig. 10 together with the equilibrium values reported so far. The oxygen amount to be balanced

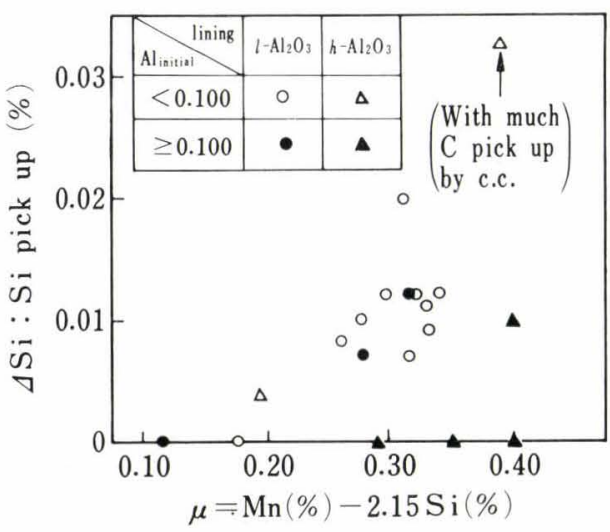

Fig. 8. Relation between Si pickup and $/$-factor

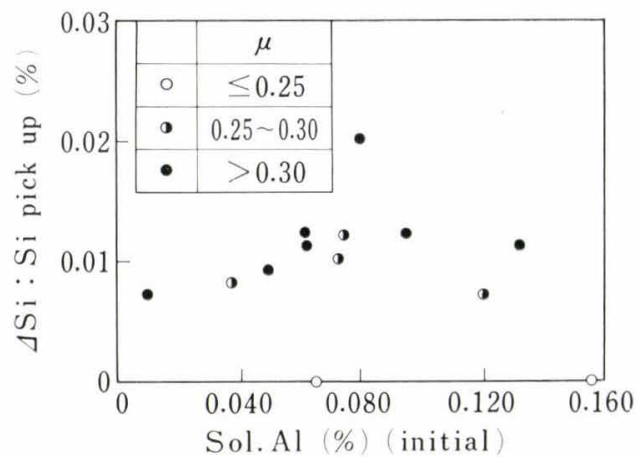

Fig. 9. Relation between Si pickup and sol. Al

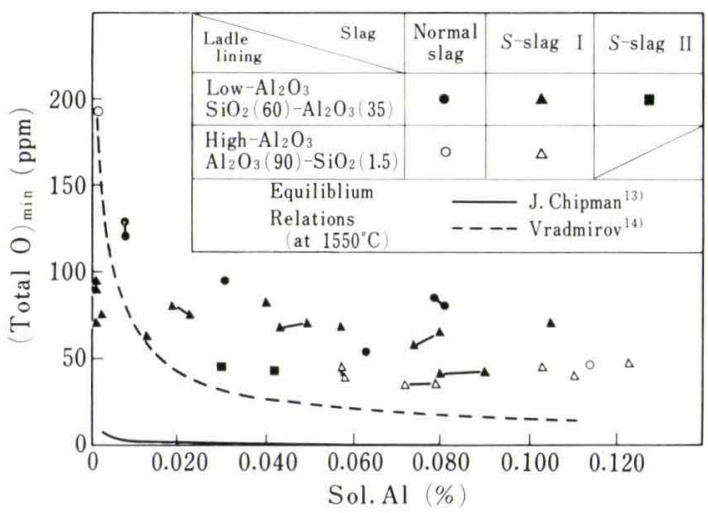

Fig. 10. Relation between Total $\mathrm{O}$ and sol. Al

increases rapidly as the amount of sol. Al decreases to below $0.030 \%$, and the same trend is clearly seen in the measured values. Figure 11 shows the relation between the (Total $\mathrm{O})_{\min }$ and the amount of $\mathrm{FeO}$ in slag at the corresponding time. It will be seen that the value of (Total $\mathrm{O})_{\min }$ decreases with the decrease in the amount of $\mathrm{FeO}$ in slag and the liquid steel becomes clean, provided that sol. $\mathrm{Al}$ is at the same level. If the amount of $\mathrm{FeO}$ is less than $2 \%$ and the amount of sol. $\mathrm{Al}$ is more than $0.030 \%$, the value of (Total O) $\min$ would become lower than $45 \mathrm{ppm}$. As to the effect of lining material, if the amount of $\mathrm{FeO}$ in slag is low, the total oxygen content would be decreased by several ppm., when a high $\mathrm{Al}_{2} \mathrm{O}_{3}$ material is used and thus the effect of lining material is observed. The difference in effects of synthetic slags I and II depending on their types is hardly observed. 


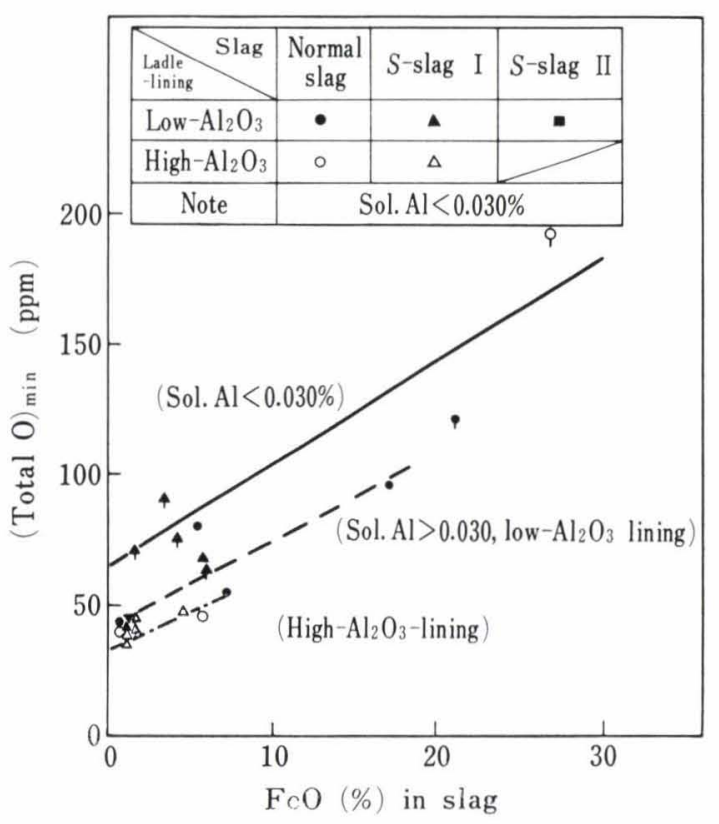

Fig. 11. Relation between minimum values of Total $\mathrm{O}$ and FeO content of slag

\section{Inclusions}

Examples of hourly changes in the number of inclusions per unit area by sizes and types and changes in the total oxygen values are shown in Fig. 12. In heat (No. 17) with $S$-slag addition large aluminaclusters decrease in quality quickly with the lapse of time and the total oxygen values also decrease down to $40 \mathrm{ppm}$. On the other hand in heat (No. 1) without $S$-slag addition large alumina clusters remain even after argon bubbling of 8 to $10 \mathrm{~min}$.

This presumably is because part of the product formed by the reaction of the slag having a high $\mathrm{FeO}$ content ( 16.3 to $5.8 \%$ ) with $\mathrm{Al}$ contained in the liquid steel is trapped therein. In other words, the decrease in inclusions $(\Delta I)$ must be expressed by the difference between the amount of inclusions eliminated through floatation $\left(\Delta I_{\text {float }}\right)$ and the amount of the trapped portion $\left(\alpha \cdot I_{\text {react }}\right)$ of inclusions reproduced $\left(I_{\text {react }}\right)$.

$$
\Delta I=\Delta I_{\mathrm{float}}-\alpha \cdot I_{\mathrm{re}}
$$

As liquid steel is stirred uniformly, the trapping coefficient $\alpha$ may well be considered as being constant. Accordingly, if the decrease of inclusions is small, this means that $I_{\text {react }}$ is great. The above-described fact means that $I_{\text {react }}$ is greatly affected by the amount of $\mathrm{FeO}$ in slag.

\section{Discussion}

1. Behaviour of Sol. $\mathrm{Al}$ and Total Oxygen (T.O) during Treatment

While the liquid steel is being stirred in a ladle, various chemical reactions as described below will occur at points (1), (2) and (3) shown in Fig. 3.

(1) Oxidation of $\mathrm{Al}$ by air and absorption of nitrogen.

(2) Oxidation of $\mathrm{Al}$ by $\mathrm{FeO}$ and $\mathrm{MnO}$ in slag and trapping of $\mathrm{Al}_{2} \mathrm{O}_{3}$ in the liquid steel. Absorption of floating inclusion.

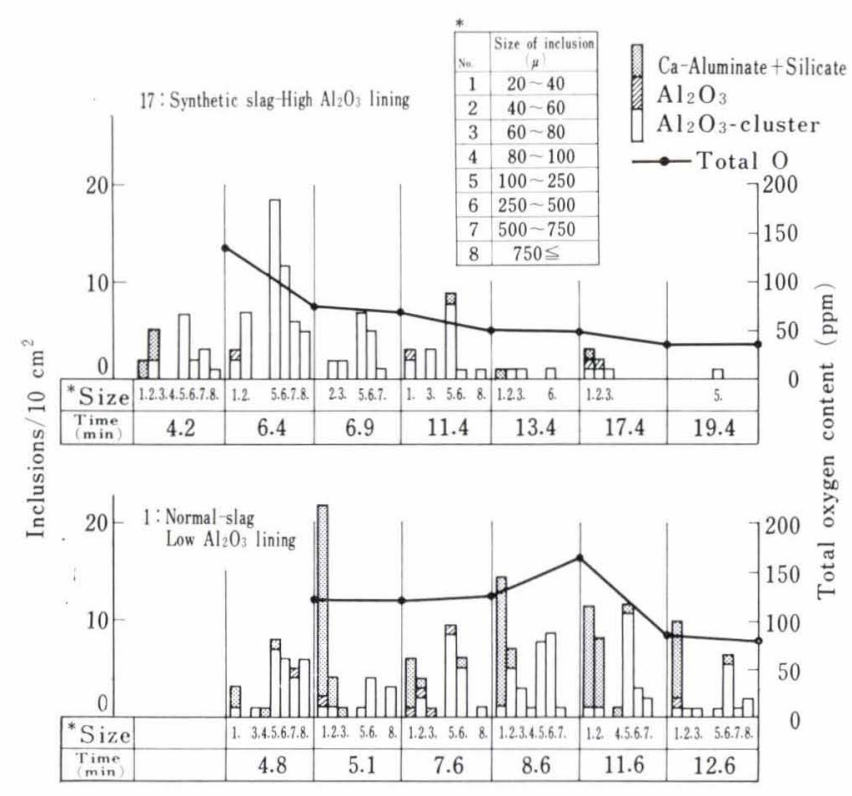

Fig. 12. Variation of inclusions and Total O during Argas bubbling

(3) Erosion of lining and reduction of $\mathrm{SiO}_{2}$ by $\underline{\mathrm{Al}}$ So far, special attention has been paid to the behaviour of total oxygen from the standpoint of purification of liquid steel. If the content of sol. Al is more than $0.030 \%$, changes in the amount of free oxygen are small. Consequently, the amount of $\mathrm{T}$. O is presumably determined by the floating separation of inclusions being suspended in liquid steel, coupled with the phenomenon wherein the oxidation product of Al produced by various reactions is trapped in liquid steel and is newly suspended. Accordingly, the rate of decreasing of T. O can be expressed by the equation

$$
-\frac{d(\mathrm{~T} . \mathrm{O})}{d t}=k(\mathrm{~T} . \mathrm{O})-\beta \cdot\left(-\frac{d \mathrm{Al}}{d t}\right)
$$

where, $\beta$ : trapping coefficient of $\mathrm{Al}_{2} \mathrm{O}_{3}$, including coefficient of conversion from $\mathrm{Al}$ to $\mathrm{O}$

$k$ : floating separation coefficient. ${ }^{16}$ )

The oxidation reaction of $\mathrm{Al}$ on the other hand may be expressed by the following formula:

$$
2 \underline{\mathrm{Al}}+\frac{3}{Y} M_{x} \mathrm{O}_{y} \longrightarrow \mathrm{Al}_{2} \mathrm{O}_{3}+\frac{3 X}{Y} \underline{M}
$$

The rate of oxidation $(-d \mathrm{Al} / d t)$ of $\underline{\mathrm{Al}}$ which is the basis of Eq. (2) was calculated, using the constant mentioned in the references, from the standpoint of the double boundary film theory for the following two cases: the case in which the oxidation rate of $\underline{\mathrm{Al}}$ is controlled by the supply of $\underline{\mathrm{Al}}$ to the reaction site, and the case in which the rate is controlled by the supply of oxygen from slag:

(1) Control by Diffusion of $\underline{\mathrm{Al}}$

In the case where the oxidation of $\underline{\mathrm{Al}}$ is assumed to be controlled by the diffusion of $\underline{\mathrm{Al}}$, the oxidation rate of $\underline{\mathrm{Al}}$ is expressed by the equation.

$$
-\frac{d[\% \mathrm{Al}]}{d t}=\frac{D_{\mathrm{Al}}}{\delta_{M}} \cdot \frac{A}{V}[\% \mathrm{Al}] .
$$




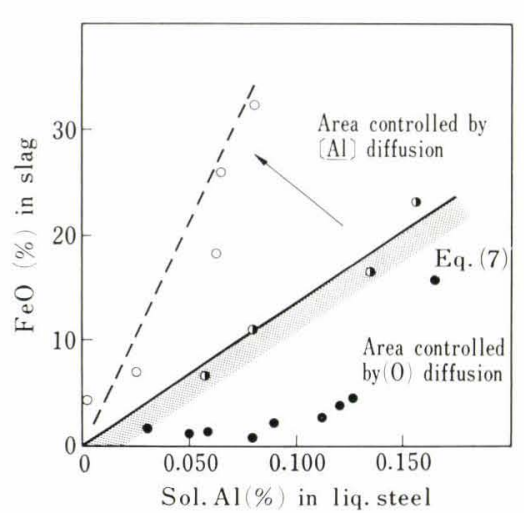

Fig. 13. Dependence of kinds of reaction control step on $\mathrm{FeO}$ content in slag and $\mathrm{Al}$ content in liq. steel

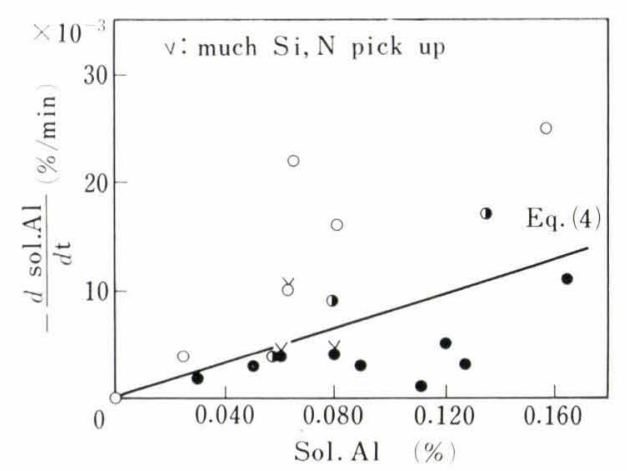

Fig. 15. Relation between ( $-d$ sol. $\mathrm{Al} / d t)$ and sol. $\mathrm{Al}$

where, $V:$ liquid steel volume $1.36 \times 10^{5} \mathrm{~cm}^{3}$

$A$ : reaction surface

$2.8 \times 10^{3} \mathrm{~cm}^{2}$ (only liq. steel-slag interface)

$1.5 \times 10^{4} \mathrm{~cm}^{2}$ (plus liq. steel-lining interface)

$D_{\mathrm{Al}}$ : diffusion coefficient of $\underline{\mathrm{Al}}$ in steel $\left.2 \times 10^{-4}{ }^{17}\right) \sim 3.5 \times 10^{-518)} \mathrm{cm}^{2} \cdot \mathrm{sec}^{-1}$

$\delta_{M}$ : thickness of diffusion layer in liq. steel side $3 \times 10^{-3}{ }^{19)} \mathrm{cm}$

Substituting the values mentioned in the references, Eq. (4) can be rewritten as follows:

$$
-\frac{d[\% \mathrm{Al}]}{d t}=\left(8.0 \times 10^{-2} \sim 1.4 \times 10^{-2}\right)[\% \mathrm{Al}] .
$$

(2) Control by Supply of Oxygen from Slag

The mole content of $\mathrm{FeO}$ to be supplied from slag per unit time is as follows:

$$
\begin{aligned}
\dot{n}_{\mathrm{FeO}} & =A \frac{D_{\mathrm{o}}}{\delta_{s}}\left(C_{\mathrm{FeO}}-C_{\mathrm{FeO}}^{i}\right) \\
& \approx A \frac{D_{\mathrm{o}}}{\delta_{s}} \cdot C_{\mathrm{FeO}} \ldots \ldots \ldots \ldots \ldots . . . . . .
\end{aligned}
$$

where, $\dot{n}_{\mathrm{FeO}}$ : mole flux of $\mathrm{FeO}\left(\mathrm{mol} \cdot \mathrm{sec}^{-1}\right)$

$C_{\mathrm{FeO}}$ : mole content of $\mathrm{FeO}$ in slag bulk (mol. $\mathrm{cm}^{-3}$ )

$C_{\mathrm{FeO}}^{i}$ : mole content of $\mathrm{FeO}$ in slag bulk at liq. steel-slag interface

$C_{\mathrm{F} e \mathrm{O}}^{i} \approx 0$ by sufficient $\underline{\mathrm{Al}}$ content

$D_{\mathrm{o}}$ : diffusion coefficient of oxygen in slag

\section{$4.9 \times 10^{-5} \mathrm{~cm}^{2} \cdot \mathrm{sec}^{-120}$}

$\delta_{S}$ : thickness of diffusion layer in slag $1.0 \times$ $10^{-2} \mathrm{~cm}^{20}$ )

$x$ : $\quad \mathrm{wt}^{\%} \% \mathrm{FeO}$ in slag $C_{\mathrm{FeO}}=3.9 \times 10^{-4} \cdot x$

The following Eq. (6) can be established from the mass balance of aluminium and oxygen to be reacted.

$$
-\frac{V \cdot \varphi}{100} \cdot \frac{48}{54} \cdot \frac{d[\% \mathrm{Al}]}{d t}=16 \cdot \dot{n}_{\mathrm{FeO}}
$$

where, $\varphi=$ density of liquid steel $\left(7.2 \mathrm{gr} \cdot \mathrm{cm}^{-3}\right)$

Substituting the constant described above, Eq. (6) can be rewritten as follows:

$$
-\frac{d[\% \mathrm{Al}]}{d t}=5.94 \times 10^{-4} \cdot x
$$

From Eqs. (4)' and $(6)^{\prime}$, the following equation can be obtained as the critical condition:

$$
\begin{aligned}
5.94 \times 10^{-4} \cdot x & =8.0 \times 10^{-2}[\% \mathrm{Al}] \\
x & =1.35 \times 10^{-2}[\% \mathrm{Al}]
\end{aligned}
$$

Comparing Eqs. (4) ${ }^{\prime}$ and (6) ${ }^{\prime}$ and based on the quantitative relation between the sol. $\mathrm{Al}$ content and the $\mathrm{FeO}$ content $(x)$ in slag, these reaction systems are divided into the range where it is controlled by the diffusion of $\underline{\mathrm{Al}}$ and the range where it is controlled by the supply of oxygen. The critical conditions for these ranges are given by Eq. (7). In Fig. 13, Eq. (7) is shown in solid lines and the initial values obtained by way of experiments are plotted therein. (Mark " $\mathrm{O}$ " indicates the range in which the oxidation rate is controlled by the diffusion of $\mathrm{Al}$; mark " $\bullet$ ", the range in which oxidation is controlled by the supply of oxygen; and mark " ", the intermediate range.) Plotting sol. Al against time for each heat, the oxidation rate of $\underline{\mathrm{Al}}$ at the early stage of reaction was obtained from the slope of plotted curve. Its relations with the amount of $\mathrm{FeO}$ or $(\mathrm{FeO}+\mathrm{MnO})$ in slag as well as to sol. $\mathrm{Al}$ are shown in Figs. 14 and 15. The effects of heats with large pickups of $\mathrm{Si}$ and $\mathrm{N}$, which are marked with " $\vee$ " in the figures, are not clear. Although these effects must be further studied, it may be appropriate in our experiment to consider that in the heats treated the oxidation rate is controlled by the supply rate of oxygen from slag.

Furthermore, the linearity of lines as shown in Fig. 
16 , illustrating the hourly changes in $\mathrm{FeO}$ content in slag, endorses that the oxidation rate of $\mathrm{Al}$ is controlled by the supply of oxygen from slag in these heats. From Eq. (8), it is considered that the difference in the slope is caused by the difference of slag amount $\left(V_{\text {slag }}\right)$.

$$
\begin{gathered}
-\frac{d(\mathrm{FeO})}{d t}=\frac{D_{0}}{\delta_{s}} \cdot \frac{A}{V_{\text {slag }}} \cdot(\mathrm{FeO}) \\
\log (\mathrm{FeO})=-\frac{1}{2.75} \cdot \frac{D_{\mathrm{o}}}{\delta_{s}} \cdot \frac{A}{V_{\mathrm{slag}}} \cdot t
\end{gathered}
$$

Based on Eq. (8) $D_{\text {o }}$ was calculated backwards from the slope of the line shown in Fig. 16, the results of which being given in Table 6. $5.62 \times 10^{-5} \sim 3.67 \times$ $10^{-5} \mathrm{~cm}^{2} \cdot \mathrm{sec}$ was obtained as $D_{0}$. This value agrees nearly with $D_{\mathrm{o}}=4.9 \times 10^{-5} \mathrm{~cm}^{2} \cdot \mathrm{sec}^{-1}$ which was used in Eq. (5). Consequently, it is considered that the boundary line indicated by Eq. (7) and shown in Fig. 13 is moved upward as shown by dotted lines, for the reason that the value used in Eq. (4) in estimating the diffusion rate of $\mathrm{Al}$ was not appropriate.

Furthermore, as the second term on the right side of Eq. (2) is proportional to the amount of FeO in slag, the relation between $(\mathrm{Total} O)_{\min }$ and the amount

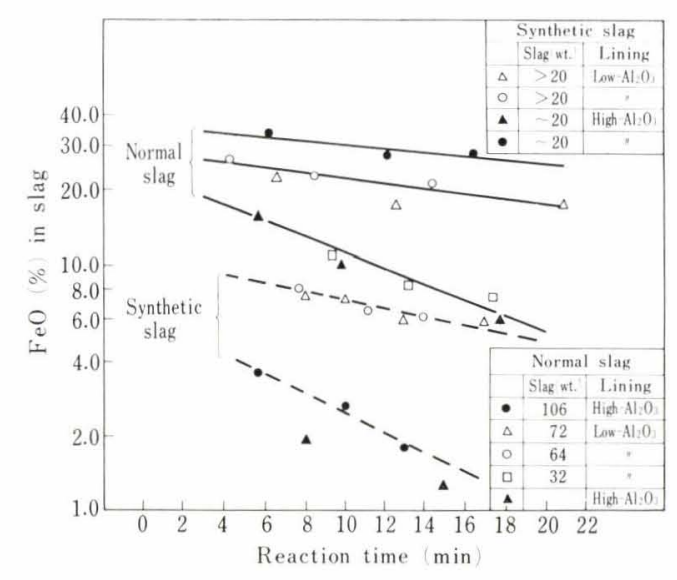

Fig. 16. Variation of $\mathrm{FeO}$ content in slag of $\mathrm{FeO}$ which is shown in Fig. 11, can be introduced as follows:

$$
-\frac{d(\mathrm{~T} . \mathrm{O})}{d t}=k \cdot(\mathrm{T} . \mathrm{O})-\beta^{\prime}(\mathrm{FeO})
$$

As $(\mathrm{T} . \mathrm{O})_{\min }$ is the amount of T. O at the time of $d(\mathrm{~T} . \mathrm{O}) / d t \rightarrow 0$, the following formulas can be obtained from Eq. (2)' :

$$
k(\mathrm{~T} . \mathrm{O})_{\min }-\beta^{\prime}(\mathrm{FeO}) \fallingdotseq 0 \quad(\mathrm{~T} . \mathrm{O})_{\min } \fallingdotseq \frac{\beta^{\prime}}{k}(\mathrm{FeO})
$$

Thus, the linear relationship between $(\mathrm{T} . \mathrm{O})_{\min }$ and the amount of $\mathrm{FeO}$ can be explained by these equations.

\section{Effect of Ladle Capacity on Loss of $\underline{\mathrm{Al}}$}

Limiting the discussion now to cases where the amount of slag is siufficently great and hence air oxidation of liquid steel can be ignored, the speed of $\mathrm{Al}$ loss by slag and the speed of Si-pick up, in two ladles of

\begin{tabular}{|c|c|c|}
\hline $\begin{array}{l}\text { Dimension } \\
\text { Ladle }\end{array}$ & $\begin{array}{l}\text { Inner diameter } \\
\qquad(\mathrm{mm})\end{array}$ & $\begin{array}{l}\text { Liq. steel head } \\
(\mathrm{mm})\end{array}$ \\
\hline $1 \mathrm{t}$ & 600 & 500 \\
\hline $150 \mathrm{t}$ & 3000 & 3000 \\
\hline
\end{tabular}
greatly different capacities, were compared on the following assumptions:

(1) Technical data of ladle

(2) The oxidizing rate of $\underline{\mathrm{Al}}$ conforms to that given in Eq. (4).

(3) Si-pick up per unit interface of ladle wall is constant regardless of the ladle size.

The results of calculations are given in Table 7 .

In a 150-ton ladle, the oxidation of $\underline{\mathrm{Al}}$ by slag is decreased to about $1 / 6$ of that in a 1 -ton ladle and the

\begin{tabular}{|c|c|c|c|c|c|}
\hline & $\begin{array}{c}\text { Slag-weight } \\
W_{s}(\mathrm{~kg})\end{array}$ & $\begin{aligned} \text { Slag-volume } \\
V_{\text {slag }}=\frac{W_{s}}{\rho_{s}} \times 10^{3} \\
\left(\mathrm{~cm}^{3}\right)\end{aligned}$ & $\begin{array}{l}\text { Tangent }=\frac{d(\log \mathrm{FeO})}{d t} \\
\left(\min ^{-1}\right) \text { (from Fig. 16) }\end{array}$ & $\begin{array}{c}K=\frac{-1}{2.75} \times \frac{A}{\delta-V_{\mathrm{slag}}} \\
\left(\mathrm{cm}^{-2}\right)\end{array}$ & $\begin{array}{c}D_{\mathrm{o}}=\frac{\text { tangent }}{K} \cdot \frac{1}{60} \\
\left(\mathrm{~cm}^{2} / \mathrm{sec}\right)\end{array}$ \\
\hline - & 106 & $35.4 \times 10^{3}$ & $8.0 \times 10^{-3}$ & 2.88 & $4.6 \times 10^{-5}$ \\
\hline$\triangle$ & 72 & $24.0 \times 10^{3}$ & $1.0 \times 10^{-2}$ & 4.24 & $3.9 \times 10^{-5}$ \\
\hline 0 & 64 & $21.3 \times 10^{3}$ & $1.0 \times 10^{-2}$ & 4.78 & $3.5 \times 10^{-5}$ \\
\hline$\square$ & 32 & $10.7 \times 10^{3}$ & $3.1 \times 10^{-2}$ & 9.26 & $5.6 \times 10^{-5}$ \\
\hline
\end{tabular}
Si-pick up is also decreased to about $1 / 5$. When a large ladle is used, the contribution of $\mathrm{SiO}_{2}$ becomes

Table 6. Calculation of diffusion coefficient

\begin{tabular}{|c|c|c|c|}
\hline \multicolumn{2}{|l|}{ Sol. Al loss or Si-pick up } & $\begin{array}{c}1 T \\
\left(\begin{array}{l}\text { Ladle dia. } 600 \phi \\
\text { liq. steel head } 500\end{array}\right)\end{array}$ & $\begin{array}{c}150 T \\
\left(\begin{array}{l}\text { Ladle dia. } 3000 \phi \\
\text { liq. steel head } 3000\end{array}\right)\end{array}$ \\
\hline \multirow{2}{*}{ Sol. Al loss $(\% / 10 \mathrm{~min})$} & When slag contains $15 \% \mathrm{FeO}$ & 0.089 & 0.015 \\
\hline & When slag contains $1.0 \% \mathrm{FeO}$ & 0.006 & 0.001 \\
\hline \multicolumn{2}{|c|}{ Si-pick up (\%/10 min), (Al equivalent) } & $0.010(0.0124)$ & $0.002(0.0025)$ \\
\hline
\end{tabular}

Diffusion layer thickness $\delta=10^{-2} \mathrm{~cm}$, Density of slag $\rho_{s}=3$, Reaction area $\mathrm{A}=2.83 \times 10^{3} \mathrm{~cm}^{2}$

Table 7. Camparion of sol. Al-loss and Si-pick up between different heat sizes 
small if the amount of $\mathrm{FeO}$ in slag is extremely high. When a synthetic slag is used, however, said contribution becomes relatively large, making it necessary therefore to give due consideration to the selection of ladle lining material.

\section{Conclusion}

In low-carbon aluminium-killed steel, the total oxygen content in the liquid steel is hardly decreased even if argon bubbling is performed, owing to reoxidation by the slag flowing from the LD-converter into the ladle. To prevent reoxidation of liquid steel by slag, synthetic slag with a low $\mathrm{FeO}$ content was produced and the purifying effect to be derived by substituting the LD-converter slag with this synthetic slag was studied, and the following results were obtained:

(1) Two systems of synthetic slags were considered usable: i.e., $\mathrm{CaO}: \mathrm{SiO}_{2}: \mathrm{Al}_{2} \mathrm{O}_{3}=38.42: 20$ (S-slag I), and $\mathrm{CaO}: \mathrm{SiO}_{2}: \mathrm{Al}_{2} \mathrm{O}_{3}=50: 7: 43$ (S-slag II). However, studies were conducted chiefly using $S$-slag I having a wider range of low melting points.

(2) The lower the FeO content in slag, the lower the total oxygen in liquid steel. If the $\mathrm{FeO}$ content in slag is lowered to 1 to $2 \%$, the total oxygen decreases to less than 40 ppm after argon bubbling of about $15 \mathrm{~min}$. Further, almost all of inclusions of more than several tens microns in size disappear.

(3) If the amount of sol. $\mathrm{Al}$ is lowered to less than $0.030 \%$, the total oxygen is rapidly increased. If the amount of $\mathrm{FeO}$ in slag is increased, the total oxygen is thereby markedly increased.

(4) When treatment with the synthetic slag is done using a ladle lined with low $-\mathrm{Al}_{2} \mathrm{O}_{3}$ material, $\underline{\mathrm{Si}}$ is picked up in an amount of 0.01 to $0.02 \%$. The zero to $60 \%$ of $\mathrm{Al}$-loss is presumably caused by its reaction with $\mathrm{SiO}_{2}$. A close relationship is observed between the increase in Si-amount and the amount of excessive Mn $(\mu)$, but Si-pick up can be prevented by using a high- $\mathrm{Al}_{2} \mathrm{O}_{2}$ lining material.

(5) It is considered that the oxidation rate of sol. Al in liquid steel by slag can be controlled by the supply of oxygen.

\section{REFERENCES}

1) Argon in der Metallurgie, B.A.S.F., Ludwigshafen am Rhein, (1966), 27.

2) H. Mcri, S. Tanaka, and I. Kokubo: 24th Joint Science Meeting, Kyushu Branch of JIM and ISIJ, July (1970).

3) F. D. Voronov, A. D. Filatov, A. E. Voronin, E. I. Rabinovich, N. M. Selivanov, G. B. Rogov, V. P. Vazhdaev, A. A Volkov, E. N. Barysheva, K. K. Biktagirov, K. K. Prokhorenko, and D. A. Dudko: Stal in Eng., (1968), 642.

4) Patent Publication No. 117379 (France), June, 1932.

5) L. N. Davydova: Stal in Eng., (1962), 810.

6) A. I. Osipov, G. B. Shirer, V. K. Komel'kov, S. G. Voinov, A. G. Shalimov, A. L. Tsibul'nikov, E. D. Mokhir, M. A. Panov, A. B. Pokrovskii, and Yu. P. Ermak: Stal in Eng., (1969), 628.

7) G. Kh. Gabuev, Yu. P. Shamil', V. V. Kurganov, G. I. Antipenko, V. M. Lyudkovskii, V. P. Potapova, V. P Frantsov, A. I. Khitrik, V. F. Smolyakav, I. P. Zavaluev, S. G. Voinov, L. F. Kosoi, V. A. Chernyakov, A. G. Shalimov, G. S. Ershov, N. N. Raskerich, and T. I. Malinovskaya: Stal in Eng., (1968), 569.

8) N. F. Dubrov, N. N. Vlasov, K. M. Petrov, E. I. Andreev, A. P. Zharkov, and M. P. Khlestkin: Stal in Eng., (1967), 214.

9) A. Muan and E. F. Osborn: Phase Equilibria among Oxides in Steelmaking, Addison-Wesley, Massachusetts, (1965), 236.

10) Y. Ohmori and T. Sanbongi: J. JIM, 22 (1958), 219

11) Y. Ohmori and T. Sambongi: J. JIM, 21 (1957), 299.

12) T. Kawawa, M. Ohkubo, and M. Ihida: Tetsu-to-Hagané, 50 (1964), 1859.

13) J. Chipman and J. F. Elliott: Electric Furnace Steelmaking, Vol. II, Interscience Pub. Ltd., New York, (1963), 133.

14) L. P. Vradmirov and N. M. Kopitsa: Steel in the USSR, 1 (1971), 873.

15) N. Mizuno and Y. Fukuda: Technical Journal of Nippon Kokan K. K., 3 (1955), 163.

16) Yawata Works, Nippon Steel Corporation: Material of 54th Steelmaking Department Meeting-Important Problems No. 6 - at Fukuyama on March 9, 1973.

17) Y. Wanibe and K. Sano: J. JIM, 30 (1966), 677.

18) E. Forster and H. Richter: Arch. Eisonhüttenw., 39 (1968), 595.

19) A.I.M.E. : B.O.H.S. New York, (1964) 611.

20) P.J. Koros and T. B. King: Trans. AIME, 224 (1962), 299. 